\title{
The muscle cell
}

\author{
J. C. SLOPER, M. C. BARRETT, AND T. A. PARTRIDGE \\ From the Department of Experimental Pathology, Charing Cross Hospital Medical School, London
}

The purpose of this review is, firstly, to outline briefly the various contractile mechanisms present in skeletal, cardiac, and smooth muscle and in other cells which contain similar mechanisms, and, secondly, to discuss the extent to which disturbances in these mechanisms can give rise to disease. The emphasis will be on those mechanisms that are particularly relevant to muscle disease, and conditions such as, for example, myasthenia gravis and experimental polymyositis that exemplify the pathological application of this newer cytophysiological information will be discussed. Reference will also be made to the pathological implications of the fact that actin and myosin and other rather similar proteins are not confined to skeletal, cardiac, and smooth muscle. Contractile elements of this kind, in conjunction with other structural proteins such as microtubules, are now thought to play a key role in the maintenance of cell shape in general, in the movement of intracellular constituents, and, indeed, in processes such as pinocytosis, phagocytosis, and secretion. It is not the presence of actin and myosin which distinguishes 'muscle cells' from 'non-muscle cells'. It is rather, firstly, the large proportion of the muscle cell cytoplasm occupied in muscle cells by the contractile proteins; secondly, the extent to which these proteins are organised into stable, highly oriented structures so arranged as to cause a specific change in the shape of the cell; and thirdly, the fact that 'muscle cells' themselves are organised into tissues that contract in a controlled and coordinated manner.

This aside, what is fascinating for the pathologist is the possibility that diseases affecting specific contractile mechanisms-for example, the membrane changes which seem to characterise certain types of myotonia-may well be found to involve many other tissues not currently thought of as part of a contractile system.

\section{Cell types}

Skeletal muscle in man constitutes about one-third of the body-weight. It is composed of tubular multinucleate cells some $10^{4}-10^{6}$ times greater in volume than a human leucocyte. Individual fibres average $40-80 \mu \mathrm{m}$ in diameter and may be as much as $300 \mathrm{~mm}$ in length (Lockhart and Brandt, 1938). As in the case of the mononuclear cells of smooth muscle and cardiac muscle the bulk of the cytoplasm is occupied by 'contractile proteins'.

\section{SKELETAL MUSCLE}

Skeletal muscle (Fig. 1) varies considerably between species and, again, within a given species. This is obvious enough when one compares in man the high innervation ratio of the eye muscles (Peachey, 1966) or of the muscle fibres of the spindles (Swash and Fox, 1976) with that found in the extrafusal fibres that constitute the bulk of limb muscles. Moreover, in man, in a given muscle, different fibre-types are found inter-digitating with each other. Thus some muscle fibres (cells) contain abundant mitochondria and are rich in mitochondrial enzymes. These predominate in postural or 'slow-twitch' muscles. They contrast with other fibres that are richer in glycogen and phosphorylase and predominate in 'fast-twitch' muscles. A critical factor in deciding the biochemical properties of the muscle fibre is the frequency of nerve-impulse reaching the fibre (Salmons and Sreter, 1976).

\section{CARDIAC MUSCLE}

Cardiac muscle, although striated, is composed of mononuclear cells closely interdigitating with each other at the intercalated discs. At these discs various forms of apposition are noted between plasma membranes of adjacent cells. These junctions include the desmosomes, the fascia adhaerens, the tight junction, and (possibly) the gap junction (Fig. 2). Desmosomal junctions provide a mechanical linkage between cells, while tight or gap junctions permit the passage of ions between adjacent cells and thus facilitate the spread of a wave of membrane depolarisation that constitutes the action potential. The pathology of these junctions has been little studied.

\section{SMOOTH MUSCLE}

Mononuclear smooth muscle cells (Figs 3 and 4) are possibly less diverse than skeletal muscle cells. Myofilaments are found to be irregularly distributed, usually in association with scattered dense bodies which possibly correspond to the Z-bands seen in 


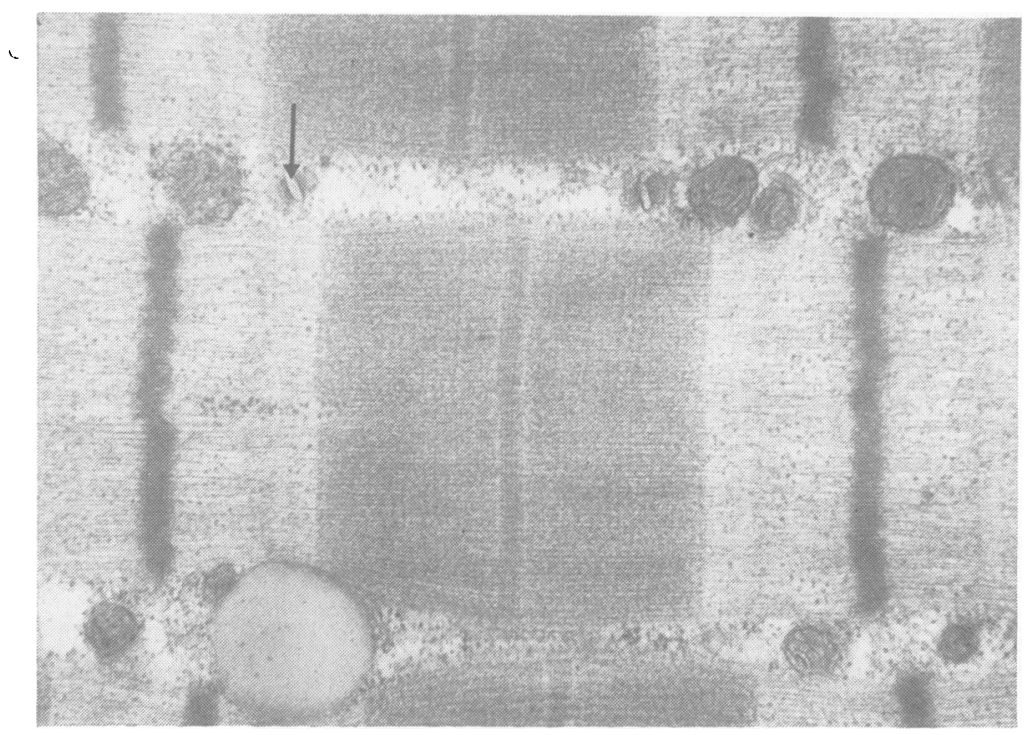

Fig. 1 Electronmicrograph of normal human skeletal muscle fixed in glutaraldehyde and postfixed in osmium tetroxide. Note A-bands, I-bands, $M$-lines, and Z-lines clearly visible, as are mitochondria. Arrowed region is the central 'transverse tubule' of a 'Triad'. The transverse tubule is an invagination of the sarcoplasmic membrane. Beside it are two sac-like structures, derived from the endop!asmic reticulum. The three comprise the Triad. $(\times 25000)$

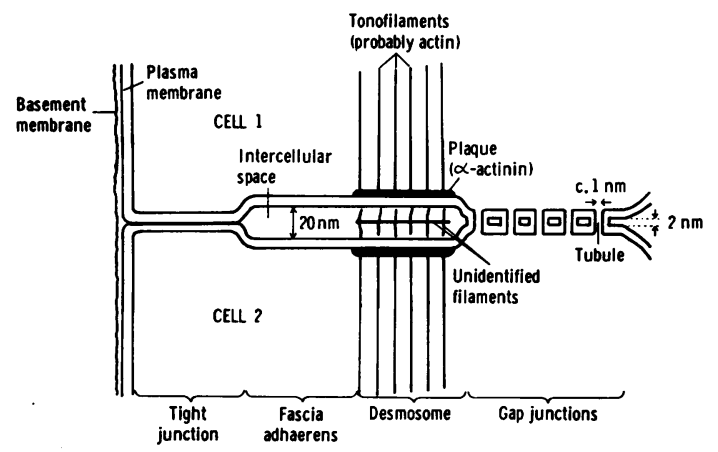

Fig. 2 Diagram showing various types of apposition ('junction') between two contiguous cells. Cell 1 (above) and Cell 2 (below) are diagrammatically represented as being joined to each other by (from left to right) $a$ tight junction, a fascia adhaerens, a desmosome, and gap junctions, the latter characterised by transverse tubules about $1 \mathrm{~nm}$ in diameter. Note that it has been necessary to use different scales in the same diagram in order to portray the fascia adhaerens and gap junctions. Note also that although all four types of junction could exist, for example, between two contiguous cardiac muscle cells these junctions would not be as near to each other as shown here. striated muscle. Intercellular material, in part a glycosaminoglycan ground substance, in part collagen fibrils, is conspicuous between smooth muscle cells. The source of these proteoglycans and other substances, such as elastic tissue, in the walls of vessels is still uncertain, for it is not always easy to define categories of fibroblasts as opposed to smooth muscle cells in the walls of vessels. In general, smooth muscle contraction is regulated by the sympathetic and parasympathetic nerve fibres by means of neurotransmitters such as noradrenaline, acetylcholine, and perhaps the purine, adenosine triphosphate (Burnstock, 1972). Other substances, including hormones, also cause contraction; for example, oxytocin contracts the pregnant uterus.

The question arises whether there is a spectrum between smooth muscle cells, in which contractile elements tend to occupy a variable but often major part of the cytoplasm, and the many other cells of the body, in which 'contractile' elements, although present, play a smaller role. Such elements mediate shape-change and shape-maintenance; they move intracytoplasmic organelles, whether nucleoproteins in mitosis or metabolic substances in the secretory process; and, by acting on the cell membrane, they 


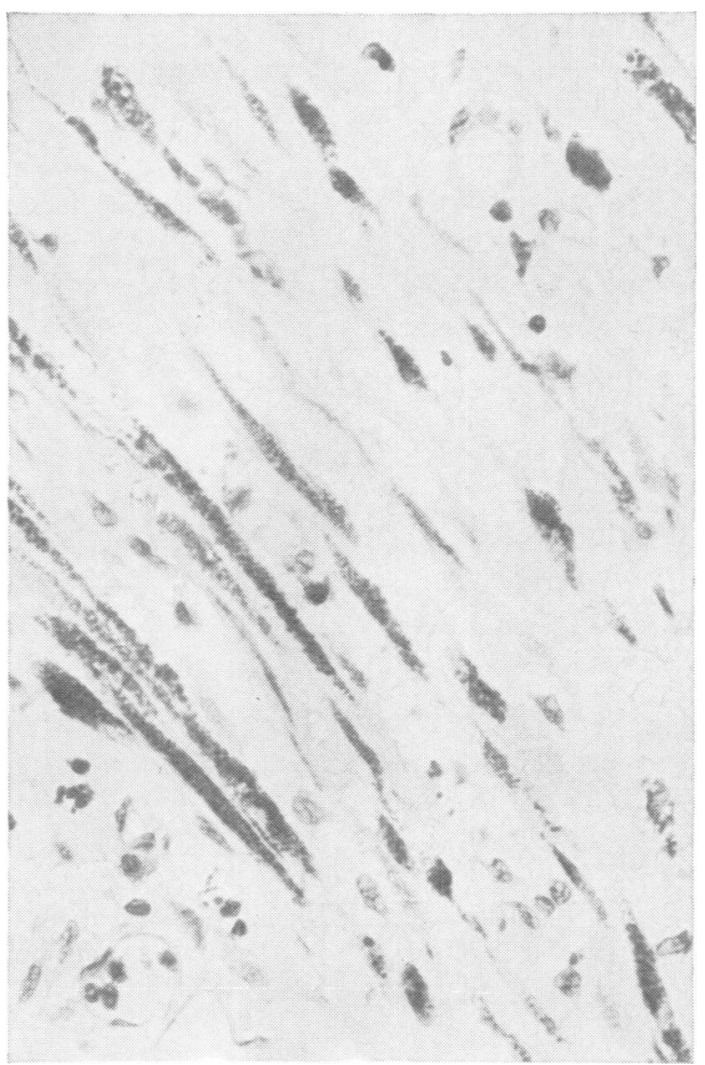

Fig. 3 Photograph of section of smooth muscle from small intestine of patient with 'brown bowel disease'. Note deposition of lipofuscin in smooth muscle cells. $(P A S /$ Tartrazine $\times 350)($ By courtesy of Dr B. Fox $)$

probably contribute to pinocytosis and phagocytosis. Again, other 'contractile' proteins provide the motive force for the movement of flagella in trichomonas and spermatozoa and of cilia in ependymal and bronchial cells and in the cells lining the Fallopian tubes and efferent ducts of the testis.

\section{Biochemical anatomy}

Although actins, myosins, and associated 'contractile' proteins are present in most cells (Table) they are highly organised in skeletal and cardiac muscle, rather less so in smooth muscle, and even less so in other cells. This organisation results in the characteristic striations of striated muscle (Fig. 5) and cardiac muscle and in the oriented contraction of these and smooth muscle.

Skeletal muscle contracts by the sliding of thick myosin filaments relative to thin actin filaments (Fig. 6a, b) (Huxley, 1957; Huxley, 1963), and possibly the same is true of smooth muscle (Fig. 7) and of 'non-muscle' cells. Actins, myosins, and associated proteins of the contractile systems of the different types of muscle cell can differ antigenically from each other (Holtzer et al., 1957). The same is probably true of the actins of platelets and leucocytes (Crawford, 1978). Conversely, 'smooth muscle antibodies' can react with the actins and myosins of 'non-muscle' cells (Farrow et al., 1971), an observation which probably explains why patients with viral hepatitis produce antisera that react with smooth muscle.

In most cells one can identify by electron microscopy microfilaments (5-7 $\mathrm{nm}$ in diameter) - that is, of the same diameter as skeletal muscle actin. There are also intermediate filaments $(10 \mathrm{~nm}$ diameter $)$ about which little is known. Myosin is present in skeletal muscle as 'thick' filaments (in contrast with actin 'thin' filaments). These myosin filaments are $10-12 \mathrm{~nm}$ in diameter. They are aggregates of myosin monomers, which are long and thin (some $160 \times 2 \mathrm{~nm})$ with a globular head region $(10 \times$ $5 \mathrm{~nm}$ ). Biochemically they are composed of two 'heavy' polypeptide chains wound round each other which diverge at one end to form a globular head with four polypeptide 'light' chains. This head region possesses ATPase activity and is also the site to which actin filaments bind during muscle contraction. The general distribution of myosin and actin can be studied by immunofluorescence in skeletal muscle, smooth muscle, and 'non-muscle' cells (Fig. 8).

Microfilaments are composed of actin in a polymeric 'fibrous' (F) form which is in equilibrium with a monomeric globular (G) form. In 'non-muscle' cells-for example, fibroblasts-the greater part of the actin may be in this dispersed $G$ form, ready to assemble rapidly into the $F$ form whenever microfilaments are needed.

In extracts from skeletal muscle the head groups of myosin molecules react with F-actin to give the appearance of regular arrays of 'arrow heads' in electronmicrographs (Huxley, 1963). This 'decoration' of actin filaments with the head groups of myosin is used as a means of identifying these actin filaments by electron microscopy in extracts from 'non-muscle cells' (see Ishikawa et al., 1969). Another characteristic of 'cytoplasmic' but not skeletal muscle actin is that some microfilaments are disrupted by the drug cytochalasin B, a fungal product (Sanger et al., 1971). Immunofluorescence reveals that actin forms a complicated network throughout the cell (Lazarides, 1976a) and that at least some of the actin filaments are attached to the plasma membrane, probably by a protein resembling $\alpha$-actinin (Schollmeyer et al., 1974b), a protein found at the $\mathrm{Z}$ line of striated muscle (Schollmeyer et al., 


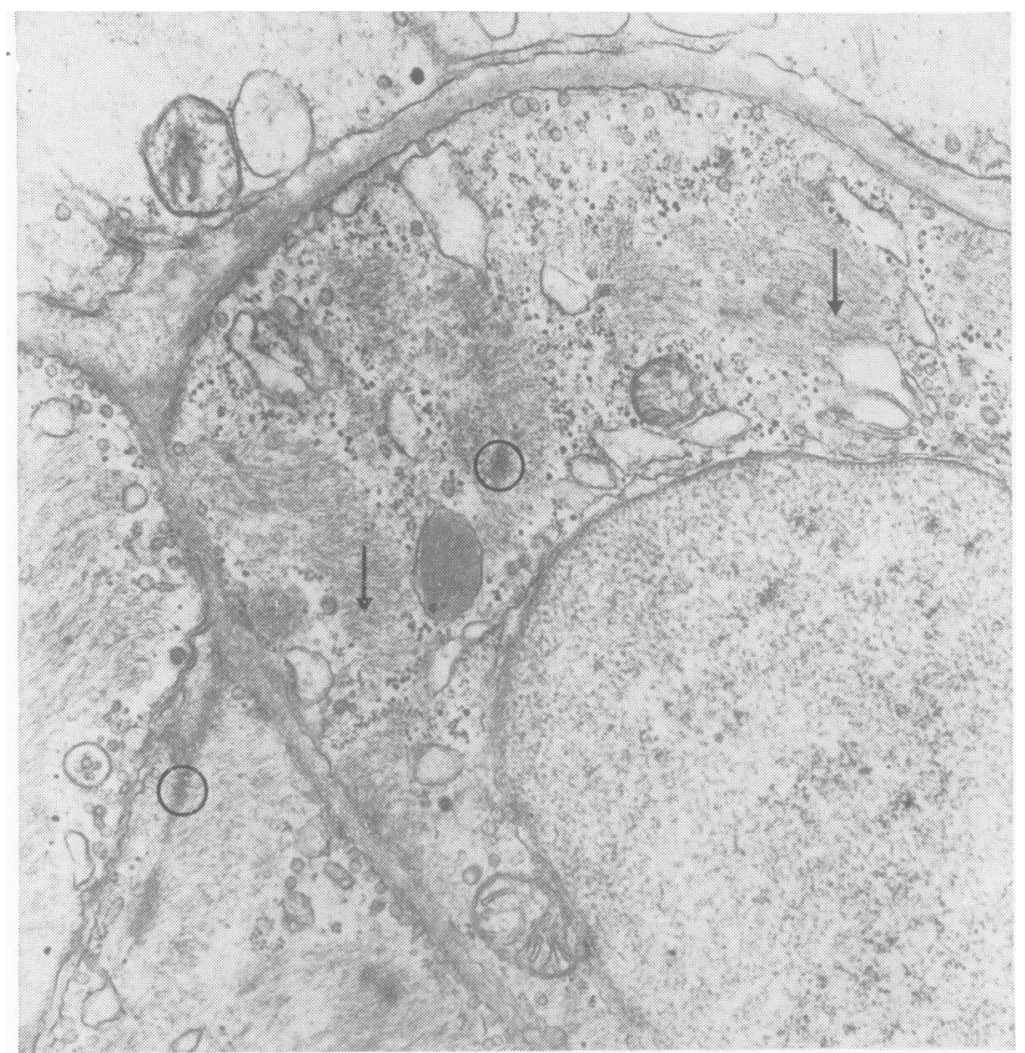

Fig. 4 Electronmicrograph of smooth muscle cell from the interlobular artery of a rat killed two days after aortic ligation. Note myofilaments (arrowed) visible as short tufts. Note also regions known as 'dense bodies' (circled). ( $\times 12$ 000). (Photograph by courtesy of Dr Shortland)

1974a). There is evidence that myosin too may be embedded in the plasma membranes of some cells (Willingham, et al., 1974).

Components of the 'contractile' system of musclefor example, myosin (Weber and Groeschel-Stewart, 1974) and tropomyosin (Lazarides, 1976b) -are also detectable in, for example, fibroblasts by fluorescent antibody tracing techniques. These proteins are not readily identifiable by electron microscopy, so their relationship with the actin molecules is not known although hypothetical models have been proposed (for example, Loor, 1976). Actin-like filaments and $\alpha$-actinin are also thought to be responsible for the 'pumping' action of microvilli, projections a few microns in length that form the brush-border of the epithelium of the small intestine (Mooseker and Tilney, 1975) and of the proximal tubules of the kidney.

Most cells contain microtubules. These can be of considerable length, are some $19-24 \mathrm{~nm}$ in diameter, and are readily demonstrated by electron microscopy and immunofluorescence (Fig. 8). They are labile and exist in equilibrium with dispersed dimers of $\alpha$ - and $\beta$-tubulin subunits. Microtubules perhaps function as a framework that interacts with the contractile elements of the cell (Rees et al., 1977). This framework can readily be demonstrated, for example, throughout the cytoplasm of the fibroblast (Weber, 1975).

Microtubules are disrupted by colchicine and vinblastin. Exactly how they participate in the movement of intracellular constituents is still obscure. They are involved, for example, in phagocytosis, in the secretory processes of liver and pancreatic cells, and in platelet contraction (see Borgers and De Brabander, 1975). They play, too, a key role in mitosis in that they largely constitute the mitotic spindle and probably participate also in axoplasmic 
Table Some proteins involved in cellular contractile processes

\begin{tabular}{|c|c|c|c|}
\hline Protein & $\begin{array}{l}\text { Molecular } \\
\text { weight } \\
\text { (daltons) }\end{array}$ & Subunit composition & Comments \\
\hline Actin & 41700 & G-actin monomer & $\begin{array}{l}\text { G-actin monomers polymerise into two strands wound round each } \\
\text { other in a helix thus forming the } F \text {-actin filament, about } 6 \mathrm{~nm} \text { diameter }\end{array}$ \\
\hline Tropomyosin & 70000 & 35000 & $\begin{array}{l}\text { Rod-shaped molecule } 40 \mathrm{~nm} \text { long which sits in grooves on the } \\
\text { F-actin filaments in skeletal muscle }\end{array}$ \\
\hline Troponin & 78000 & $\begin{array}{l}1 \times 37000(\text { Troponin-T) } \\
1 \times 23000 \text { (Troponin-I) } \\
1 \times \quad 18000 \text { (Troponin-C) }\end{array}$ & $\begin{array}{l}\text { A troponin complex sits on an actin monomer every } 38.5 \mathrm{~nm} \text { along } \\
\text { the 'thin' filaments of skeletal muscle }\end{array}$ \\
\hline$\alpha$-Actinin & 180000 & $2 \times 90000$ & $\begin{array}{l}\text { Thought to connect actin with membrane structures-for example, at } \\
\text { Z-discs, at tips of microvilli, and at desmosome plaques }\end{array}$ \\
\hline Tubulin & 120000 & $2 \times 60000$ & $\begin{array}{l}\text { Two subunits, each about } 4 \mathrm{~nm} \text { in diameter, polymerise into 'micro- } \\
\text { tubules' of overall diameter } 19-24 \mathrm{~nm}\end{array}$ \\
\hline Dynein & $?$ & $\begin{array}{l}1 \times 600000(14 S \text { subunits }) \\
2 \times ?(30 S \text { and } 4 S \text { subunits })\end{array}$ & $\begin{array}{l}\text { The 'arms' on microtubular doublets of cilia and flagella. } \\
\text { Possess ATPase activity }\end{array}$ \\
\hline
\end{tabular}

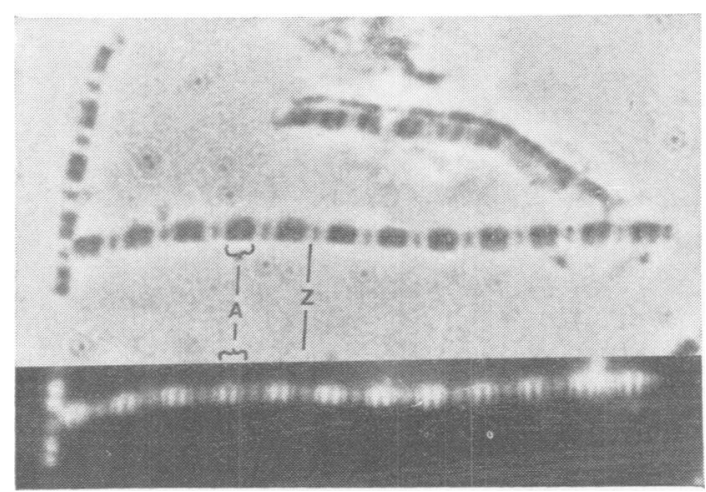

Fig. 5 Myofibril teased from mouse skeletal muscle after treatment with $50 \%(\mathrm{~V} / \mathrm{V})$ glycerol for 3 weeks at $-20^{\circ} \mathrm{C}$. Upper photograph shows myofibril examined by phase contrast microscopy. Lower photograph shows same myofibril treated with guinea-pig anti-muscle antibody and then with FITC-rabbit anti-guinea-pig Ig and examined by fluorescence microscopy. Note fluorescent staining of A-bands and Z-lines. ( $\times 2000)$.

transport (see Ochs, 1971; Sloper and Grainger, 1975), perhaps in conjunction with 'contractile proteins' (Bray, 1977). However, the best understood role of microtubules in cell movement relates to the 'beating' of cilia. Here dynein arms appear to cause a sliding movement between neighbouring pairs ('doublets') of microtubules (Fig. 9). Dynein is a protein which, like myosin, possesses ATPase activity (Gibbons and Rowe, 1965).

Muscle cells, apart from the highly oriented arrangement of their 'contractile proteins', differ from most tissue cells in that their contractile activities are co-ordinated. Thus in skeletal muscle (Fig. 6a) an impulse which arrives at the motor nerve terminal results in the release of acetylcholine. This diffuses across the narrow space between nerve terminal and the muscle cell surface to become bound to an acetylcholine receptor protein located in the motor end-plate region of the muscle fibre. Binding initiates a local depolarisation which is then propagated over the entire plasma membrane of the muscle fibre and down the tubular invaginations of the plasma membrane (the $\mathrm{T}$ system) deep into the muscle fibre.

Depolarisation of the $T$ system causes $\mathrm{Ca}^{++}$ release from sac-like portions of the sarcoplasmic reticulum (endoplasmic reticulum of muscle), which lie closely applied to the tubules of the $\mathrm{T}$ system. These $\mathrm{Ca}^{++}$ions become bound to troponin (Fig. 6b), which undergoes a conformational change and causes the associated tropomyosin molecule to change its position with regard to the F-actin filament to which it is attached. This change permits head groups of myosin molecules to bind to and move actin fibrils towards the centre of the myosin 


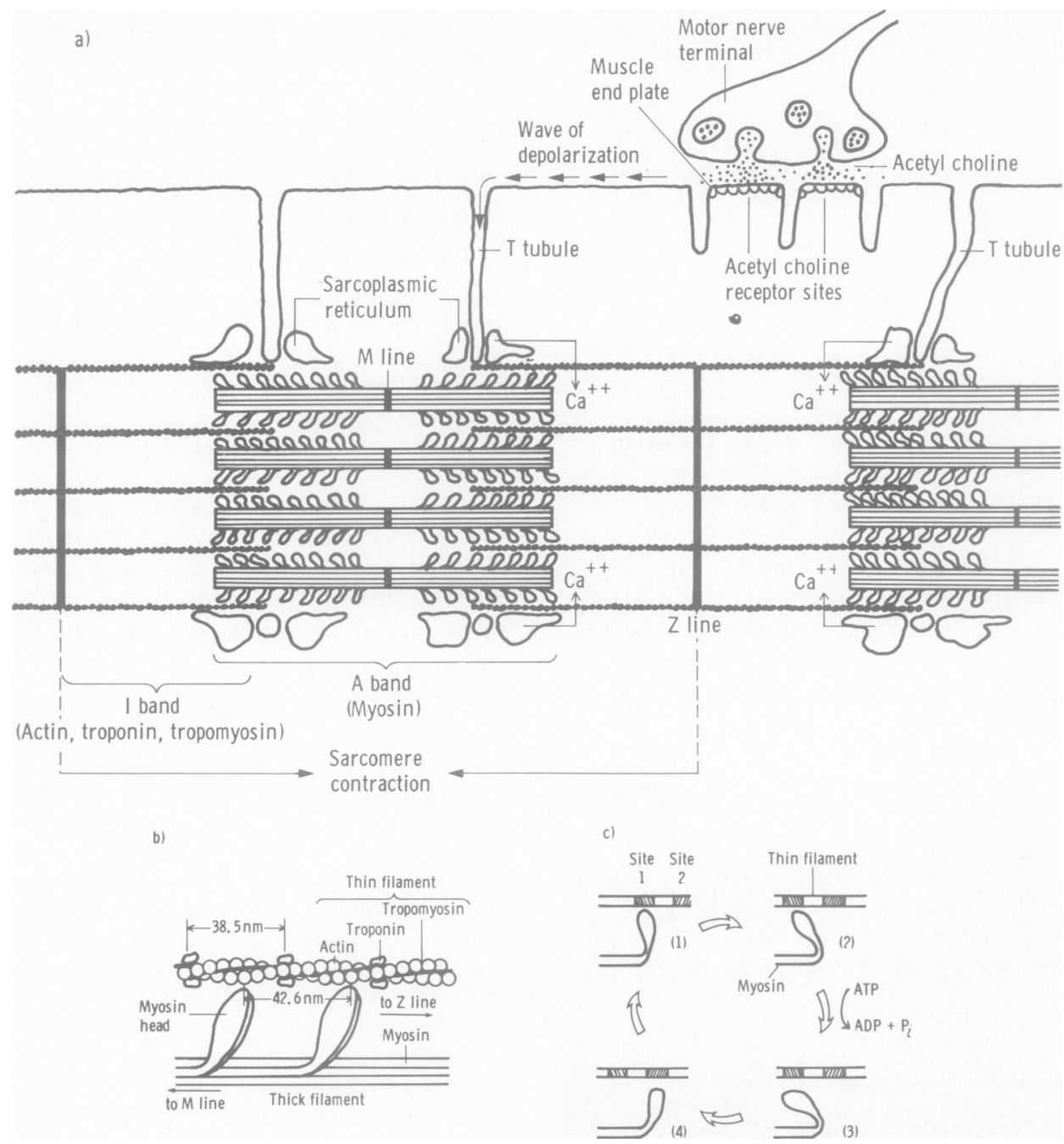

Fig. 6 (a) Diagrammatic representation of part of innervated skeletal muscle cell showing the sarcomere components, the sacs of sarcoplasmic (endoplasmic) reticulum, the way in which these sacs are apposed to the T-tubule system (thus forming the Triad), the continuation of the wall of the T-tubule system with the plasma membrane, and the relationship of the acetylcholine receptor sites to the motor nerve terminal. (b) Diagrammatic representation of the components of the 'thin' filaments. Also shown is the interaction between the head groups of myosin in the 'thick' filaments with actin of the 'thin' filament. Calcium released from the sarcoplasmic reticulum binds to a subunit of the Troponin complex thus causing a conformational change in that complex. This change allows tropomyosin to move, thus unmasking the myosin-binding sites of monomers (G-actin) of the F-actin filament. (c) Diagram showing relative movement of the 'thin' and 'thick' filaments during muscle contraction. In step 1 a myosin head group, with bound $A D P$ and $P_{1}$ (inorganic phosphate), becomes attached to a G-actin monomer at site 1 on the 'thin' filament. The myosin head group undergoes a conformational change such that the angle between the head group and the tail of the myosin molecule in the 'thick' filament is altered. This results in the 'thin' filament being moved (to the left in the diagram) along the 'thick' filament (step 2). As the result of hydrolysis of ATP by the ATPase activity of the myosin head group, the myosin molecule becomes detached from the G-actin monomer at site 1 (step 3): the angle between the head group and the tail of the myosin molecule reverts to its 'resting' configuration opposite a different part of the actin filament (step 4). In a single sarcomere, if one imagines contraction drawing together the Z-lines of the sarcomere, the actin filaments will move in relation to stationary myosin filaments. 


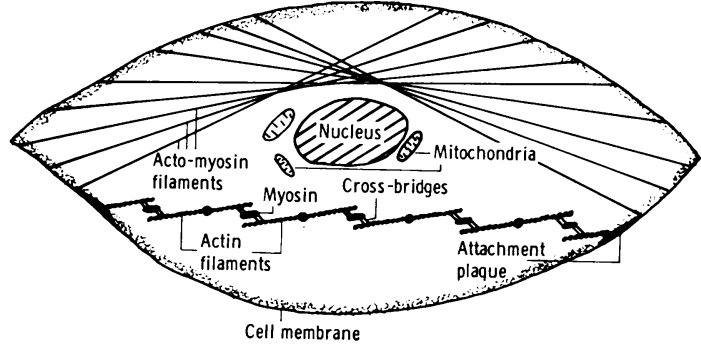

Fig. 7 Hypothetical arrangement of actomyosin filaments in smooth muscle cell. Filaments are attached at each end to the cell membrane via 'attachment plaques'. The arrangement of filaments across the cell (top half of illustration) is drawn at a different scale to the hypothetical arrangement of actin and myosin in single filaments (lower half of illustration). 'Dense bodies' are probably situated midway along each individual F-actin filament and possibly represent some form of anchorage. The polarity of the actin molecules on one side of a dense body is probably opposite to that of the actin molecules on the other side of the dense body. In this way it has been suggested that the sliding filament hypothesis for muscle contraction in striated muscle may also be applicable to contraction in smooth muscle cells (after Small and Squire, 1972).

A-band. The sarcomere is thus shortened. The myosin head-groups then release their hold on actin, a process requiring the hydrolysis of ATP by the ATPase activity of the myosin head-group.

Sustained contraction is achieved by the repetition of this cycle (Fig. 6c). Contraction ceases as $\mathrm{Ca}^{++}$ ions are pumped back into the sarcoplasmic sacs. This causes a fall in the concentration of calcium ions in the region of the myofibrils and thus the release of these ions from the myofibrils-that is, from troponin. The cessation of contraction follows the return of the tropomyosin molecule to the position where it prevents interaction of myosin head groups with actin (see Huxley (1972) for a more detailed description).

It is of pathological interest that in rigor mortis, because of the lack of ATP, the head-groups of myosin cannot detach themselves from actin fibrils to which they are bound. In osteomalacia muscle weakness may reflect an abnormality in the sequestration of calcium ions by the sarcoplasmic reticulum (Schott and Wills, 1976). This process in vitamin-D deficient rabbits seems to result from the impaired ability of sarcoplasmic reticulum to concentrate calcium ions (Curry et al., 1974).

The mode of action of the actins and myosins found in 'non-muscle' cells such as fibroblasts is obscure. The use of cytochalasin-B as a disrupter of cytoplasmic actin filaments (microfilaments) led to the suggestion that actin and myosin participate in a wide variety of cellular processes (Wessells et al., 1971). In non-muscle cells actin and myosin may by their interaction contribute to locomotion, modification of cell shape, endocytosis and exocytosis, and division of the cell body. Hypothetical examples of such mechanisms are shown in Fig. 10. Equally, generation of tension by fibroblasts during wound contraction and by platelets during clot retraction probably reflect in part the interaction of actin and myosin.

\section{Development, hyperplasia, growth, and repair}

The cellular mechanisms underlying the initial development, growth, and repair of skeletal muscle seem to be essentially the same. It was long thought that injured skeletal muscle was repaired almost entirely by scar tissue, but it has been widely recognised in recent years that muscle repair is accompanied by abundant new muscle formation (Sloper and Pegrum, 1967). The underlying mechanisms of muscle regeneration were once commonly thought to be by amitotic division of muscle nuclei (Godman, 1958.) This theory is now largely discarded (Fischman, 1972). Current thought is largely based on the studies of Holtzer (see Lash et al., 1957, and Konigsberg, 1963). Their work suggested that myonuclei-that is, the nuclei of muscle fibres and of their precursors the multinucleate myotubesdo not divide. Mitotic division is confined to mononuclear muscle-cell precursors, which fuse together to form myotubes (Fig. 11).

Convincing evidence in favour of the fusion of mononuclear precursors during development has been provided by Mintz and Baker (1967). They combined the morulae of different strains of mice, thus producing mosaics. By using isoenzymes as markers they showed that hybrid isoenzymes were produced in the skeletal muscle of such mice-that is, that these animals contain fibres that must have arisen by fusion of cells derived from two different strains of mouse.

Gross changes in musculature are induced in a variety of conditions-for example, in skeletal muscle after training and in the uterine wall in pregnancy. These changes are commonly attributed to the hypertrophy of muscle cells rather than to the formation of new cells. The explanation is probably an over-simplification. Thus the rapid induction of hypertension in the rat is accompanied by a proliferation of arteriolar smooth muscle but not of cardiac muscle cells as judged by the uptake of tritiated thymidine (Crane and Ingle, 1965; see Shortland et al., 


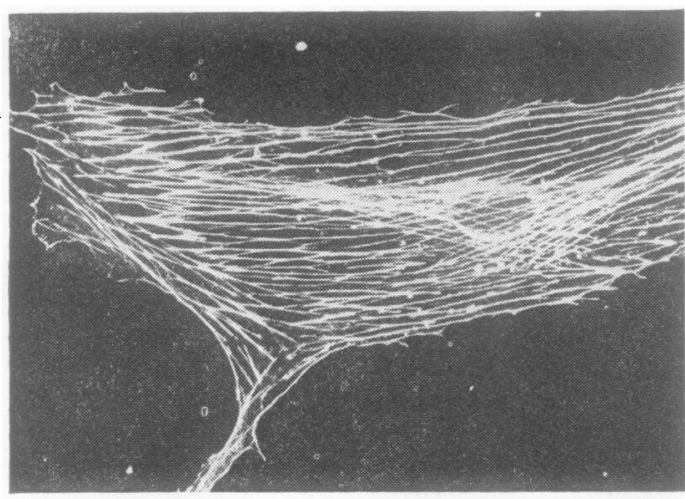

$8 \mathrm{a}$

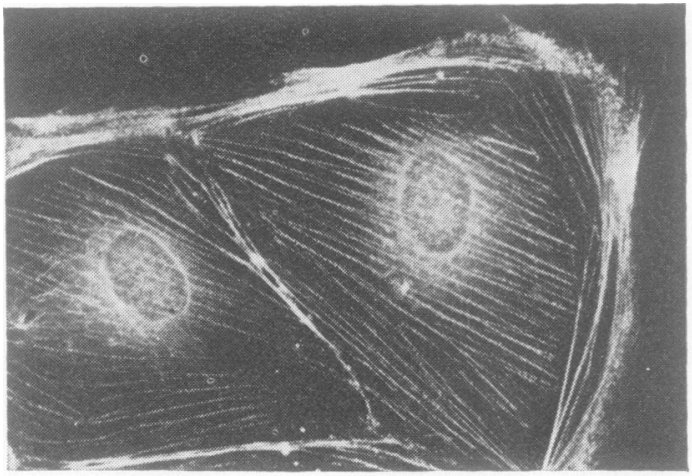

$8 b$

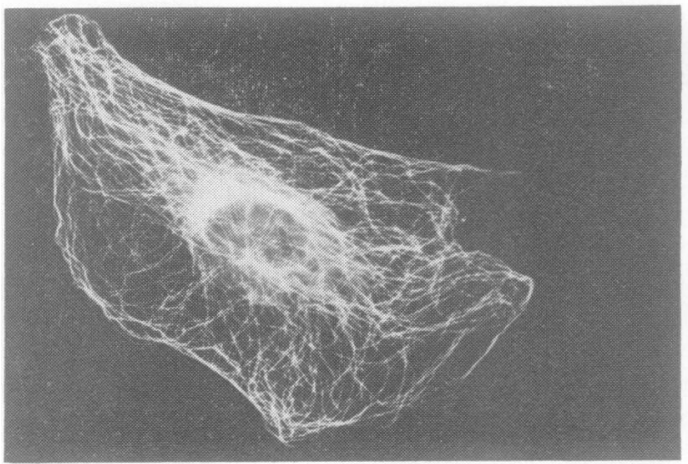

$8 \mathrm{c}$

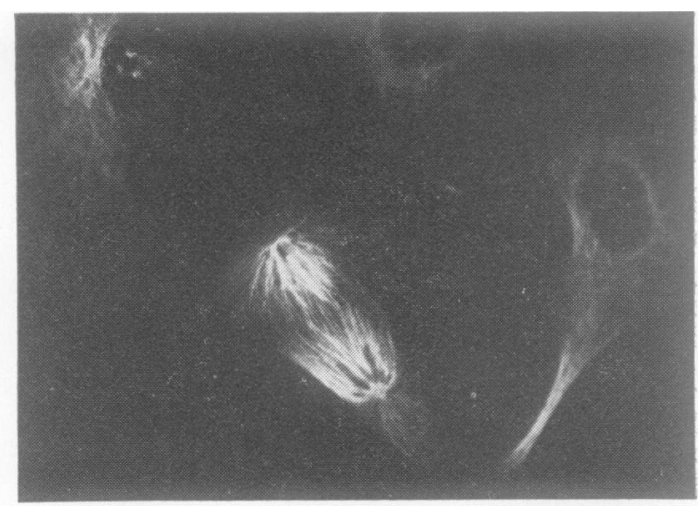

$8 \mathrm{~d}$

Fig. 8 Demonstration of actin, myosin, and tubulin in cells by immunofuorescence. (a) Cultured rat cell treated with anti-actin antibody. Note highly organised system of straight fibres, often running parallel for long distances, sometimes converging at focal points.

(b) Cultured cell of an epithelioid line $\left(P t K_{1}\right)$ from kangaroo rat treated with anti-gizzard myosin. Note 'interruptions' in myosin stress fibres. (c) Mouse $3 T 3$ cell treated with anti-pig brain tubulin antibody showing cytoplasmic microtubules. (d) Pt $K_{1}$ cell in late anaphase treated with anti-pig brain tubulin. Note tubulin present in the cytoplasmic microtubules and microtubules of the mitotic spindle. (Photograph by courtesy of Dr Klaus Weber and by permission of the Elsevier/North-Holland Biomedical Press) 


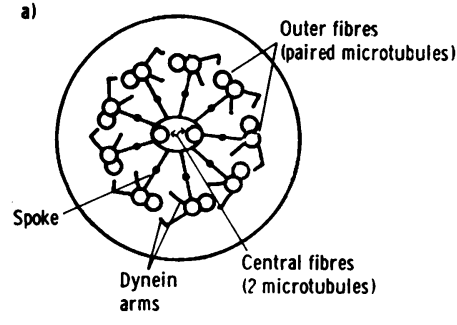

Movement of microtubule doublet

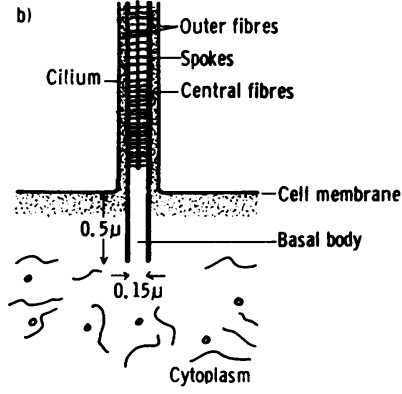

Fig. 9 (a) Diagram of section of cilium showing arrangement of nine outer fibres of microtubular 'doublets' linked via 'spokes' to the central fibres (two microtubule 'singlets'). Dynein 'arms' link adjacent microtubule doublets. (b) Diagram of cilium at level of the cell surface. (c) Diagram of four of the nine microtubule doublets (outer fibres) in a cilium. Dynein arms on one microtubule doublet act on adjacent microtubule doublet causing it to move as illustrated.
1970 for ultrastructural changes).Similarly,Goldspink (1974) explains the increase in myonuclei observed during growth and during work 'hypertrophy' of skeletal muscle in terms of proliferation of 'satellite cells' and the fusion of their progeny with the adjacent muscle fibres. These apparently undifferentiated mononuclear 'satellite' cells lie between the plasma and basement membranes of the muscle fibre (Mauro, 1961). Such cells are thought to give rise to muscle precursors which multiply to become myoblasts that can fuse and become incorporated within the multinucleate muscle fibre.

Again, it was argued until recently that little new muscle was formed when smooth, cardiac, or skeletal muscle was damaged (McMinn, 1969). But we know, at least in the case of injured skeletal muscle, that abundant new muscle cells are formed. Walker (1963) in particular established the relevance of these findings to muscle repair in vivo. Mononuclear muscle cell precursors are probably derived from satellite cells or from myonuclei segregated from the cytoplasm of injured muscle fibres, although other possibilities such as the derivation of myoblasts from interstitial cells or from exogenous, perhaps circulating, cells (Fig. 12) have yet to be excluded (Sloper and Pegrum, 1967; Bayliss and Sloper, 1973).

Whether fibroblasts or myoblasts can migrate through tissues is still undecided. Abercrombie (1978) reports (see page 1) that fibroblast scan move in vitro. We have been studying grafts of minced skeletal muscle (Studitsky, 1974) made between strains of mice differing in their isoenzymic forms of malate dehydrogenase and glucose-6-phosphate isomerase. The studies indicate that connective tissue cells, including fibroblasts and skeletal muscle cell precursors, can enter grafts (Partridge and Sloper, 1977).

Now it has been shown that when normal skin is transplanted into the skin of a patient with Hunter's syndrome (a mucopolysaccharidosis associated with mental deficiency) there is an increased urinary secretion of glycosaminoglycans (see M. F. Dean (Dean, 1978) at page 120). This suggests that the transplanted fibroblasts have made up in part for the deficient $\alpha$-L-idurono-2-sulphate sulphatase in the grafted patient (Dean et al., 1976). It would be very exciting if in the near future we could similarly attempt to insert normal myoblasts into patients with congenital muscle disorders. Because muscle cells are multinucleate and because the gene products of individual nuclei seem to be shared, at least to some extent, within the fibre (Mintz and Baker, 1967) new normal myonuclei could possibly make up for an enzyme deficiency in an abnormal muscle fibre.

It should be added that the differentiation of myotubes into muscle fibres is accompanied by the migration of myonuclei to the periphery of the cell. Moreover, once newly formed muscle fibres become innervated by motor nerve terminals acetylcholine receptors become restricted to small areas on the surface (Diamond and Miledi, 1962) underlying the nerve terminal. These areas, with their infolded primary and secondary clefts, characterise the motor end-plates. If muscle fibres lose their innervation acetylcholine receptors again become widely dis- 
a)

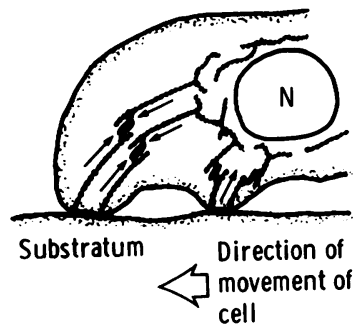

b)

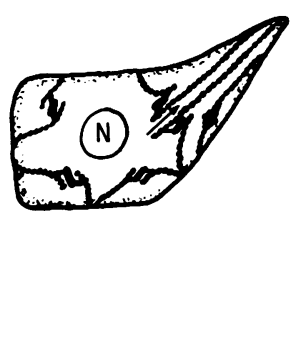

c)

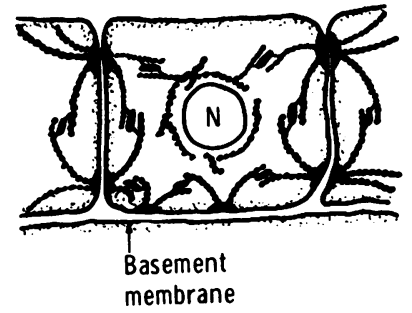

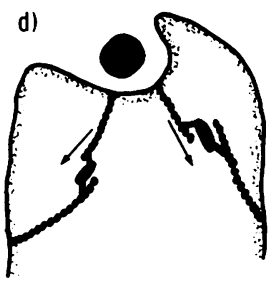

e)
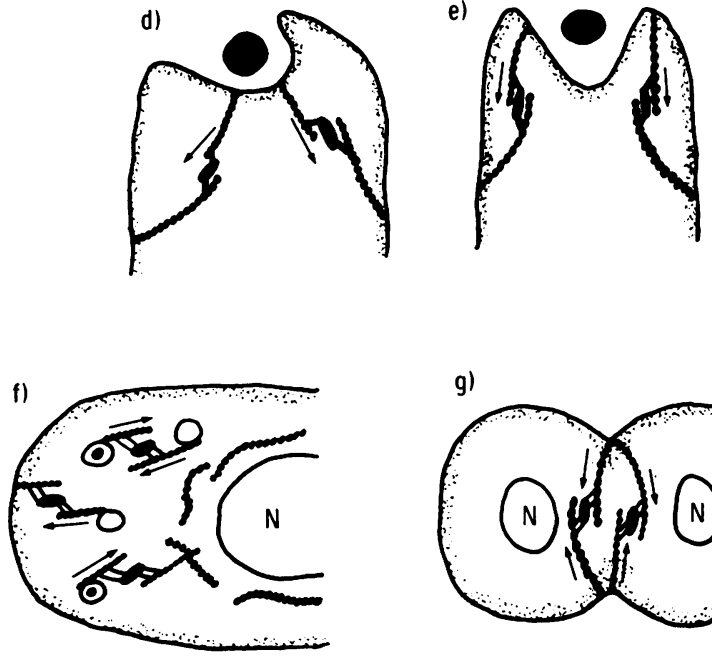

g)

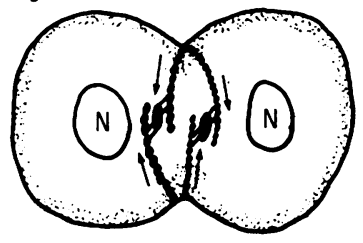

Fig. 10 Hypothetical models of mechanisms by which actins and myosins may participate in various cellular activities. Actin filaments are drawn out of scale as 'strings of pearls' with myosin molecules forming the cross links between the actin filaments. (a) Locomotion. In cells ( for example, fibroblasts) crawling on a surface actin-like microfilaments run obliquely backwards to the nuclear region from points of contact between the cell and the surface. Tension developed in the actomyosin filaments appears to pull the cell forward. (b) Cell shape. Development of tension in actomyosin filaments in the subsurface network of filaments probably helps the cell to hold its shape. In addition some finger-like outpushings of the cell-for example, microvilli in the brush border of the renal proximal tubule-are supported by a central core of actin-like microfilaments. (c) Adhesion. Points of adhesion of a cell to surrounding structures (other cells, basement membranes, collagen fibrils) are dispersed over the cell surface. These attachments sites are mechanically linked to one another by microfilament bundles so that a disruptive force applied locally is shared among all the adhesive contact sites. (d) Endocytosis, including phagocytosis, pinocytosis, and micropinocytosis. Ingested particles or fluids are enclosed in a portion of the cell membrane pinched off as a vesicle within the cytoplasm. Since cytochalasin E inhibits endocytosis and disrupts microfilaments these microfilaments probably play a part in endocytosis.

(e) Exocytosis, including secretion. When particles or substances contained within membrane-bound vesicles are expelled or secreted from the cytoplasm the membrane of the vesicle fuses with the plasma men:brane. This process depends upon microfilaments. Note that in endocytosis the filaments are inserted differently into the cell rembrane. (f) Movement of particles within cells. Phagocytic vacuoles, lysosomal vesicles, $n$ itochondria, pigment granules, and secretory vesicles all appear to be moved within the cytoplasm by energydependent processes probably centering on microfilaments. Three possible mechanisms of such movement are shown, all based on the sliding filament hypothesis of actin and myosin interaction. (g) Cytokinesis. The process whereby a cell separates into two parts after nuclear division. It is dependent on microfilaments and may occur by a mechanism analogous to the drawing of a purse string. 

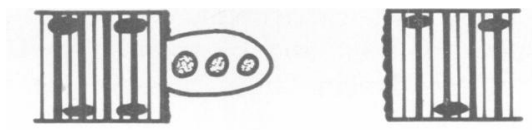

FUSION OF MONONUCLEAR PRECURSORS

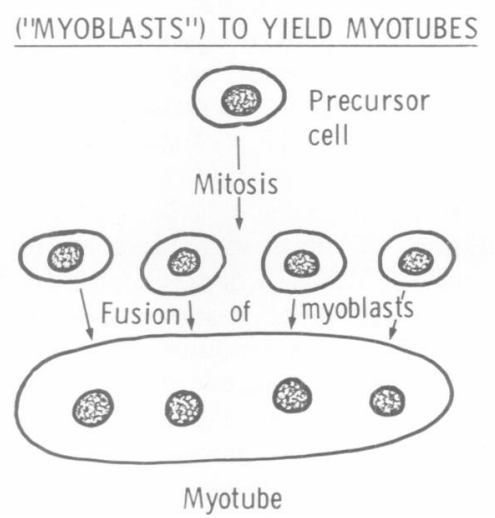

Fig. 11 Upper diagram: hypothesis, largely discarded, that myotubes originate as 'buds' from existing injured muscle fibres (cells). Lower diagram: currently widely accepted view that mononuclear muscle precursor cells undergo a series of mitotic divisions yielding myoblasts which fuse to form multinucleate myotubes: these mature into adult muscle fibres.

persed over the muscle cell surface (Axelsson and Thesleff, 1959). Nearby nerve fibres will often bud out towards the denervated muscle fibre and form new endings (Hoffman, 1951). Reinnervation in this way imposes upon the muscle fibre the enzyme type ('fast' or 'slow') characteristic of the nerve (Romanul and Van der Meulen, 1966; Bullen et al., 1969; McComas, 1977). End-plates (and motor terminals) vary greatly in their shape in disease; they are particularly large in myasthenia gravis.

Diseases of contractile mechanisms in 'non-muscle' cells

POSSIBLE ACTIN ABNORMALITY IN POLYMORPHONUCLEAR LEUCOCYTES

An abnormally functioning actin has recently been reported (Boxer et al., 1974) in the polymorphonuclear neutrophil leucocytes (PMN) of an infant suffering from recurrent bacterial infections and unable to produce pus. The phagocytic activity of this patient's monocytes was normal, but the locomotion and particle-ingestion of his PMN were much impaired (Fig.13). Myosin and tubulin extracted from PMN appeared normal by electrophoresis, whereas actin monomers, although present, failed to polymerise normally. The most conspicuous morphological abnormality was the formation of few and thin pseudopodia in PMN spread on glass and the development of few filament-rich pseudopodia, as seen by electron microscopy. It has similarly been suggested (Booyse et al., 1972) that an abnormality of platelet actomyosin ('thrombasthenin') may explain the failure of platelet aggregation and clot retraction seen in Glanzmann's thrombasthenia, a bleeding disorder.

POSSIBLE MICROTUBULAR ABNORMALITY IN POLYMORPHONUCLEAR LEUCOCYTES

A defect in microtubular function may underlie a further genetically-determined syndrome, the Chediak-Higashi syndrome, characterised by abnormal PMN function and by the presence of giant lysosomes in such cells (Oliver, 1975). In man the features include albinism and nystagmus and frequent pyogenic infections (Blume and Wolff, 1972). Oliver's suggestion of an underlying abnormality in microtubular function rests on the fact that 

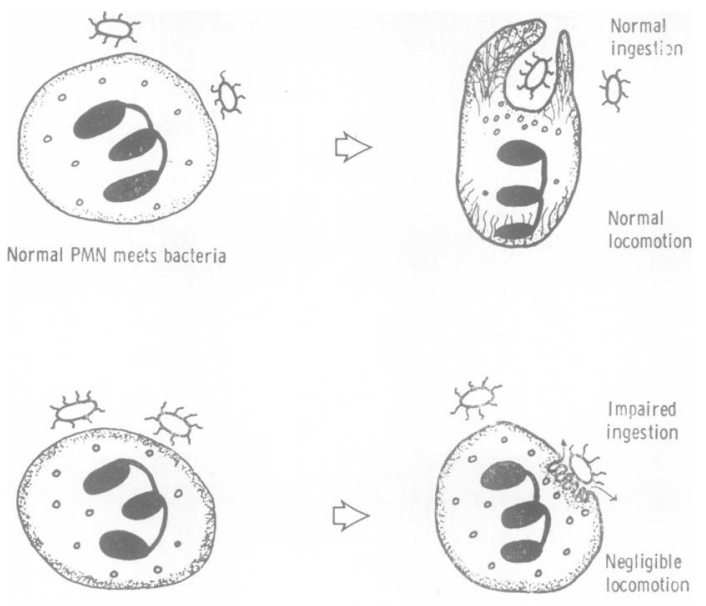

Patient's PMN meets bacteria

Fig. 13 Diagram of PMN function in normal subject and in patient with impaired PMN function. In normal subject contact with bacterial cell causes PMN to move towards and ingest foreign cell. These functions are facilitated by the polymerisation of $G$-actin monomers so that F-actin filaments are formed. These are attached to the cell membrane and participate in locomotion and endocytosis (Fig. 10). PMN function is impaired when $G$-actin cannot polymerise, endocytosis is diminished, and locomotion impaired. (After Boxer et al., 1974)

colchicine, which disrupts microtubules, causes normal PMN to behave like those in the ChediakHigashi mouse. Whether the fault lies in the microtubular proteins themselves or in the mechanisms controlling microtubular assembly and disassembly has not been fully investigated. We owe to the pioneer work of Malawista (1975) our knowledge of the way in which microtubules contribute to PMN function and the degranulation of lysosomes.

ABNORMAL DYNEIN-MICROTUBULAR SYSTEM IN DISEASES AFFECTING CILIA A generalised disease involving the dynein-microtubular system, the 'immotile-cilia' syndrome, has recently been characterised in man (Afzelius, 1976; Eliasson et al., 1977). The assembly of dynein on to the tubulin of microtubules of flagella and cilia is affected (see Fig. 9 for normal structure). There may be an underlying deficiency in the synthesis or assembly of dynein or in the proper attachment of dynein to microtubules. Male patients are infertile and, as in Kartagener's syndrome, have chronic respiratory disease. These are attributed to flagellar and ciliary dysfunction, respectively, in spermatozoa and bronchi. There may also be malposition of the viscera, a reduced sense of smell, headaches, and mental depression. Electronmicrographs of cilia of the respiratory tract and of sperm flagella show a lack of the dynein 'arms' seen in the normal cilium (Fig. 9a).

\section{Diseases of smooth muscle}

Diseases of smooth muscle are usually attributed to disturbances in control mechanisms. This applies to the megacolon of Hirschsprung's disease, in which it is widely accepted that the prime abnormality is in the autonomic innervation of the large intestine.

A well-recognised change, however, which primarily affects the muscle cells themselves is the accumulation of lipofuscin pigment in atrophic smooth muscle. This can be so excessive as to justify the term 'brown bowel' disease, a form of lipofuscinosis in which large amounts of this pigment can be seen in the smooth muscle of the gut and also in that of the arterioles (see Fig. 3). This is sometimes associated with malabsorption or with low vitaminE concentration in the plasma (Fox, 1967).

Primary diseases of smooth muscle are probably commoner than we realise. It would be of interest to seek changes in smooth muscle fibres and in their attachments to each other in conditions such as the megacolon of hypothyroidism and in the fibrosis of the oesophagus in scleroderma. There is, too, the question of the mechanisms which give rise to cystic medial degeneration of the aorta, a condition associated not only with old age but also with pregnancy and with arachnodactyly (Marfan's disease), where there is a general loosening of ligamentous attachments (see C. I. Levene, (Levene, 1978) at page 82). This form of medial degeneration has been attributed variously to a disorder of ground substance, elastic tissue, fibrous tissue, or smooth muscle in the media of the aorta. In the future we must define, perhaps in vitro, whether the site of the primary abnormality lies in the smooth muscle cell, in fibroblasts responsible for forming and maintaining the other elements of the aortic wall, or in some cell intermediate between 'fibroblast' and myoblast (Gabbiani et al., 1973). The technical difficulties involved in distinguishing between these categories of cell are ably discussed by Abbott et al. (1974) and Chamley et al. (1977).

\section{Disease of skeletal muscle}

DISEASES AFFECTING MOTOR INNERVATION In many diseases of skeletal muscle the mechanisms of motor innervation are at fault. It is often difficult to decide whether a given condition is primarily myopathic or neuropathic, not least because the maturation of the muscle fibre depends on its motor 


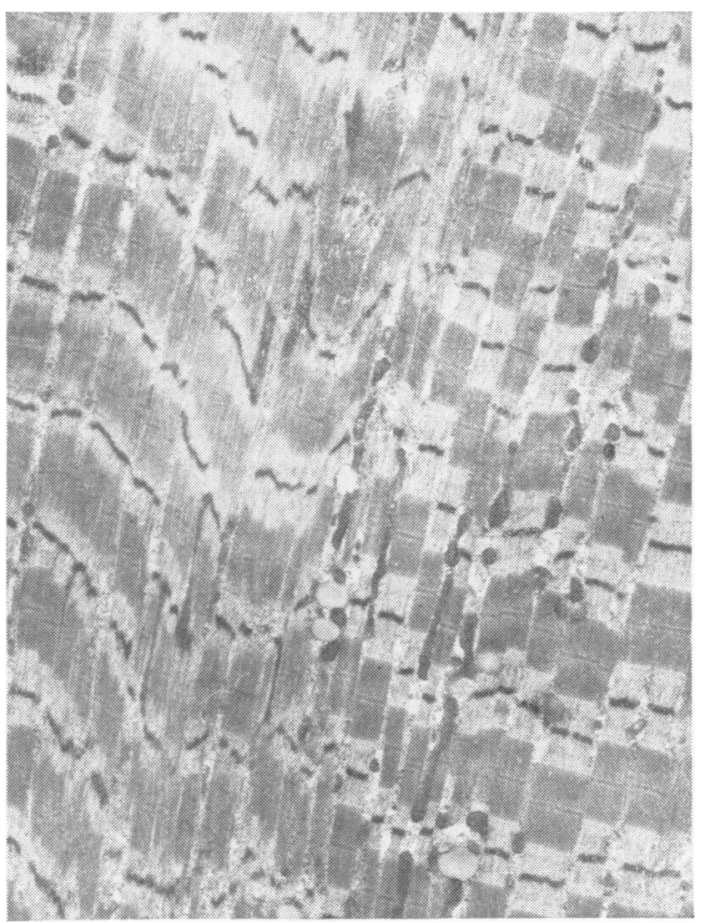

Fig. 14 Muscle from right thigh of a woman aged 26 suffering from muscle weakness. Muscle biopsy showed very low levels of phosphorylase $b$, low levels of cAMPdependent protein kinase, and high glycogen content. Electronmicrograph of tissue fixed in glutaraldehyde and postfixed in osmium tetroxide. Note ill-defined individual myofibrils in middle of micrograph: this is a 'structured central core'. Contrast this with regions on either side where normal myofibrils are well separated. In the core region Z-line thickening and 'streaming' is evident and mitochondria are absent. $(\times 6800)$.

innervation. This process of maturation is characterised by an increase in fibre diameter, by the migration of myonuclei to the periphery, by the acquisition of different enzymatic characteristics in different types of muscle, and by the development of a specialised motor end-plate region. Denervation reverses these processes and may induce changes which can be mistaken for evidence of a primary myopathy (Gutmann and Zak, 1961). The interplay between the motor nerve and the skeletal muscle is discussed by McComas (1977), who takes the view that many so-called myopathies may be secondary to a primary neuropathy. Conversely, Cosmos (1974) ably discusses the effect of myopathic changes on the motor nerve.

A number of conditions exemplify myopathies. They include myasthenia gravis in the form that primarily affects the acetylcholine recepturs; myotonia congenita and myotonia dystrophica, that affect the electrical properties of the muscle cell membrane; myopathies associated with abnormal myosins; the myopathies associated with other biochemical disturbances; and allergic polymyositis, in which cell-membrane and contractile proteins are probably involved.

\section{Myasthenia gravis}

This term covers a number of disorders of neuromuscular transmission. There are probably variants where the primary disorder is within the axon ('presynaptic'), within the space between axon terminal and the primary and secondary clefts of the motor end-plate, or at the surface of the end-plate ('postsynaptic'). Intravital staining of preterminal nerve fibres has revealed the formation in some cases of many end-plates on a single muscle fibre. This change can be interpreted as an attempt by the motor nerve fibre to increase its area of contact with the muscle cell. Axons of such nerve terminals appear ultrastructurally normal but there is typically a widening and flattening of the primary and secondary clefts of the end-plate, on which the acetylcholine receptors are situated (Engel and Santa, 1971). $\alpha$-Bungarotoxin, an extract of the venom of a banded krait, binds specifically to these receptors and, when labelled with ${ }^{125} \mathrm{I}$, has been

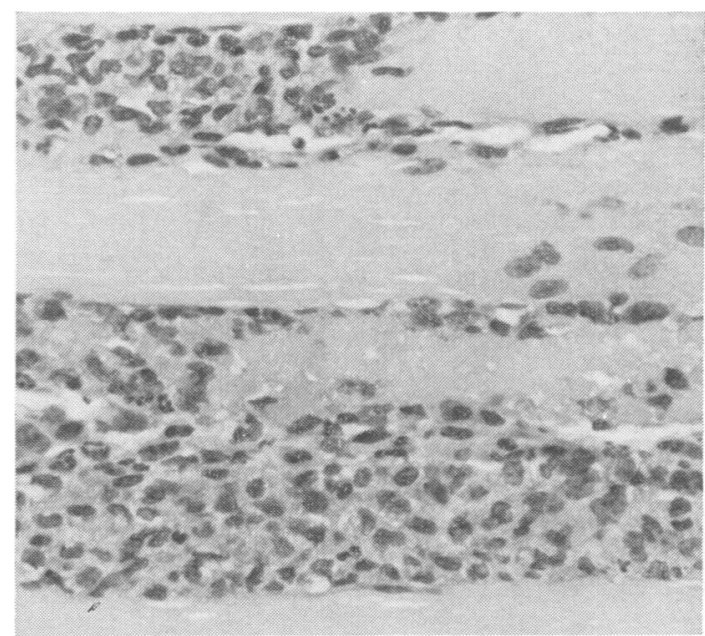

Fig. 15 Photomicrograph of section of muscle from guinea-pig with experimental myositis. Note extensive infiltration of inflammatory cells and loss of fibre architecture. (Haematoxylin and eosin $\times 300$ ). 


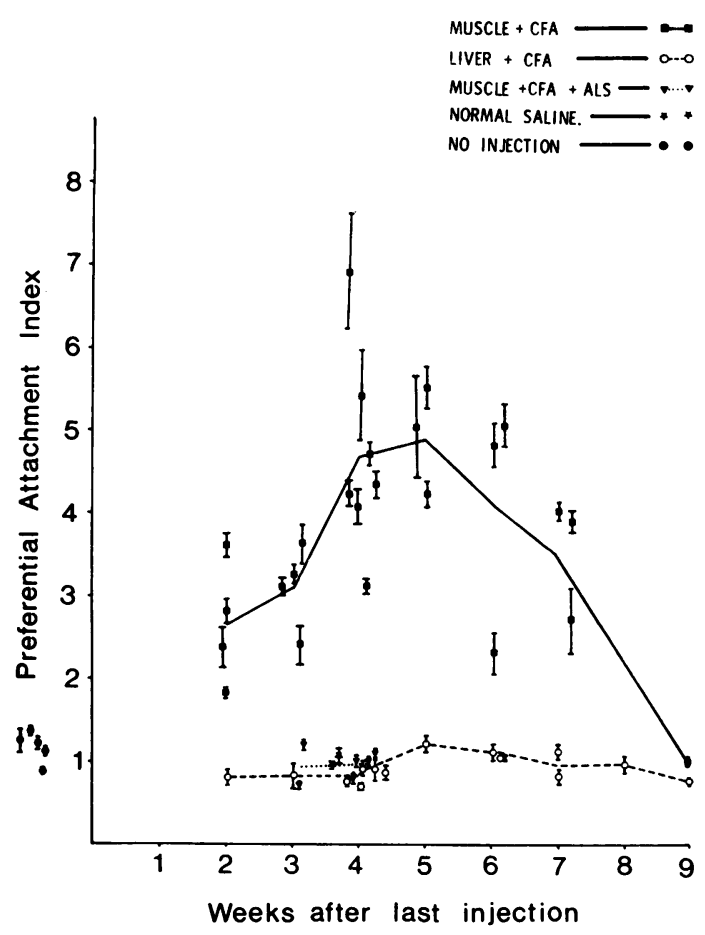

Fig. 16 Experimental polymyositis in guinea-pigs. The preferential attachment index gives a measure of the tendency of lymphocytes from the blood or lymph nodes of experimental animals to attach themselves to chick myotubes in culture as opposed to interstitial cells, including fibroblasts. Myositis is produced in animals injected with muscle plus complete Freund's adjuvant and is blocked by giving anti-lymphocyte serum ( $A L S)$. Only animals injected with muscle plus CFA four times weekly developed myositis, and only in these animals was the preferential attachment index raised above 1 (indicating the preference of lymphocytes to attach to myotubes in culture rather than to fibroblasts). The $P A$ index was maximal four weeks after the last injection of muscle plus CFA when lesions were most widespread. Index measurements for uninjected animals are shown on left of figure.

used to demonstrate receptor sites (Fischbach and Cohen, 1973).

Interest at present centres on what is probably the commonest variety of the myasthenic syndromenamely, that in which a circulating antibody blocks the acetylcholine receptor sites. In such myasthenic subjects the number of sites that will bind labelled bungarotoxin is diminished (Fambrough et al., 1973). Circulating antibody is present in many patients (Lindstrom et al., 1976). Removal of this antibody by plasmapheresis greatly alleviates the myasthenia
(Pinching et al., 1976b). Evidence of localisation of IgG and $C_{3}$ at the motor end-plate of myasthenic patients has been presented by Engel and his coworkers (Engel et al., 1977b). This strongly confirms the idea (Simpson, 1960) that myasthenia gravis may have an autoimmune basis.

The key experimental model is based on the injection of acetylcholine receptor material with complete Freund's adjuvant into rats. The receptors are derived from the electric organs of the eel (Electrophorus electricus). There is an initial phase (Engel et al., 1976), 24 hours or so after the onset of weakness, characterised by mononuclear, neutrophil, and rare eosinophil infiltration of the end-plate region. Engel's ultrastructural studies are quite extraordinarily thorough and reveal macrophages at this stage entering the gaps between the separating clefts of the end-plate. This phase may be accompanied by evidence of a disturbance in cell-mediated immunity (Lennon et al., 1976), although the disorder can be induced by the transfer of antibody from affected animals (Lindstrom et al., 1976a). The chronic phase is essentially humoral and characterised by the appearance of circulating antibody against receptor sites and degeneration of the endplate receptor site.

Other varieties of myasthenia gravis, which do not appear to involve autoimmunity, are encountered occasionally (Pinching et al.,1976; Engel et al.,1977a).

\section{Myotonia congenita and myotonia dystrophica}

In myotonic subjects muscular contraction is unduly prolonged because there is a failure of prompt muscle relaxation owing to the repetitive firing of action potentials by the muscle membrane. A myotonic person finds it impossible to let go of a door-handle, for example. The phenomenon of 'myotonia' can be caused by a variety of conditions such as hyperkalaemic familial periodic paralysis, hypothyroidism, vitamin E deficiency, or after treatment with such drugs as clofibrate (McComas, 1977). Myotonia congenita and myotonia dystrophica are both characterised by this phenomenon. In the latter there is an associated muscle degeneration.

The myotonia in these conditions may reflect a disturbance in the biophysical and biochemical properties of the muscle plasma membrane. The key observations are derived from studies made in human patients (Lipicky and Bryant, 1973) and in goats with a similar syndrome (Bryant and MoralesAguilera, 1971) which have revealed a decreased chloride-permeability of the muscle membrane.

In skeletal muscle a wave of depolarisation of the resting potential is propagated along the plasma membrane and down the $T$ (transverse) tubule system. The normal muscle plasma membrane is 
freely permeable to potassium ions, which diffuse out of the fibre to restore the resting potential after depolarisation. Adrian and Bryant (1974) hold that in normal muscle the high $\mathrm{Cl}^{-}$permeability of the membranes of the T-system helps to compensate for the reduced resting potential caused by build-up of potassium ions in the tubules during repetitive muscle stimulation. In myotonic goats the membrane permeability to $\mathrm{Cl}^{-}$is decreased so that repetitive stimulation diminishes the resting potential in the membranes of the $T$ tubules: this renders these membranes likely to 'fire' spontaneously.

The underlying biochemical abnormality in the muscle membrane is uncertain. Analyses of muscle and of red cell membranes from affected subjects have shown differences between normal and myotonic subjects with respect to membrane fluidity (Butterfield et al., 1974), fatty acid content (Kuhn, 1973), and the phosphorylating ability of protein kinases (Roses and Appel, 1973).

This use of red cells for membrane studies in muscle disease is exciting great interest. The underlying inference is that a crucial membrane disturbance in muscle may be reflected in other tissues. Interestingly enough, an abnormally high proportion of red cells in patients with Duchenne muscular dystrophy can be shown to have hedgehog-like projections ('echinocytes'). This change certainly suggests a cell-membrane abnormality (Matheson and Howland, 1974).

\section{Myopathies associated with abnormal myosins}

Although inherited disorders of myosin have yet to be defined in man such a disorder has been seen in a 'floppy' mutant of a nematode worm (Caenorhabditis elegans). Microscopically there is a marked deficiency in myofibrils. This is attributed to a deficiency in one of the genes coding for one of the heavy chains of myosin (MacLeod et al., 1977). The quest for abnormal myosins and other enzymes in human myopathies of unknown cause is an active field of contemporary research.

A genetic disorder of myofibril formation has also been reported in the axolotl. This probably reflects an abnormality of cardiac myosin (Lemanski, 1974). Cardiac muscle is involved in diseases such as Duchenne dystrophy regarded as primarily skeletal myopathies (Walton and Natrass, 1954).

\section{Myopathies with other specific biochemical disturbances}

These are well reviewed by Dubowitz and Brooke (1973) and Gardner-Medwin (1977). Some, such as the malignant hyperthermia associated with muscle destruction which develops in susceptible patients under anaesthesia, are little understood. Many of these patients have a high plasma CK level. Nelson (1973) has suggested that the underyling disorder is a failure of the sarcoplasmic reticulum to concentrate $\mathrm{Ca}^{++}$.

Rather better analysed are the glycogenoses (Ryman, 1974) in which the enzymes of glycogen metabolism are lacking. These disorders can affect many tissues, but in McArdle's disease (McArdle, 1951) the deficient phosphorylase seems to be specific to muscle. We have recently seen a variant of McArdle's disease in which the condition was associated with the curious morphological change which characterises another myopathy-namely, 'central core disease' (Fig. 14).

Lipid myopathies are described, for example, where there is a deficiency in carnitine palmityl transferase (DiMauro and DiMauro, 1973) or carnitine (Engel and Angelini, 1973). In such myopathies lipid vacuoles may be conspicuous in muscle

There is also a wide variety of myopathies characterised by abnormal organelles: in these myopathies the underlying biochemical abnormality is not known. Some may be characterised by what are probably abnormal Z-bands (the 'myotubular' myopathies); others, the 'megaconial' myopathies, are associated with abnormally large mitochondria (Dubowitz and Brooke, 1973). These diseases are thought to be confined to skeletal and sometimes cardiac muscle. What is not known about many of these conditions is the extent to which they may or may not involve 'non-muscle' cells.

\section{Polymyositis}

Idiopathic polymyositis is a progressive, sometimes fatal inflammation of muscle of no known cause. First well characterised by Walton and Adams (1958), a good experimental model was developed by Dawkins (1965) who injected whole rabbit muscle homogenate with complete Freund's adjuvant into guinea-pigs. Our findings corroborate and extend those initiated by Kakulas (1966) and Currie (1971). Our aim was to clarify the way in which muscle was attacked. We used Dawkins's model, which yielded an active myositis with myonecroses in almost all animals appropriately injected and killed at the height of the disease (Fig. 15). We also developed a method of quantifying lesions. The high reproducibility of the disease allowed us to determine which ultracentrifugal fraction of muscle on injection yielded most lesions.

Only the myofibrillar fraction yielded lesions comparable with those obtained with whole muscle homogenate (Manghani et al., 1974). Curiously, this fraction had not been tested by others, although some -for example, Morgan et al. (1971) - obtained a myositis with a mitochondrial fraction. Our work 
does not rule out the possibility that the critical antigenic substance in muscle may lie in a membranous or other component brought down in the myofibrillar fraction. It strongly suggests, however, that the myofibrillar fraction is the most effective in producing a myositis.

We next studied the role of serum and of lymphocytes in the production of the disease. Sensitised lymphocytes transferred from animals with active myositis caused the disease in 16 out of 20 recipient animals, but transferred serum did not in any of 10 animals studied. The role of antibody has yet to be excluded. We found high levels of circulating antibody in animals with myositis. Just possibly we did not give sufficient antibody in our transfer experiment to produce a myositis.

The question we then asked ourselves was: Against what fraction of muscle are lymphocytes from such animals sensitised? We found that they were sensitised against whole muscle homogenate and myofibrillar subfractions such as myosin and tropomyosin but not against troponin (Smith and Partridge, 1976).

The next question was: How do sensitised lymphocytes find and gain access to the interior of the muscle cell? In human polymyositis one can suppose that there is some change in the muscle cell surface which excites the immune system in such a way that it attacks the subject's own muscle cells. Injection of muscle and Freund's complete adjuvant possibly mimics this process, modifying the immune system of the body in such a way that lymphocytes will attack muscle. Indeed, Kakulas (1966) showed that lymphocytes from myositic animals would destroy tissuecultured muscle cells. We studied the way in which such lymphocytes adhered preferentially to muscle cells in tissue culture before destroying these cells, and we developed a method of quantifying preferential adherence (Partridge and Smith, 1976). Such adherence was maximal when muscle lesions were most frequent. Treatment with antilymphocytic serum blocked both the disease and the preferential attachment of the lymphocytes to muscle. It blocked too the development of lymphocytes sensitised against specific muscle fractions (Fig. 16).

The two tests we used are proving effective guides in the diagnosis of human polymyositis. In these studies the macrophage migration inhibition test has been replaced by the leucocyte migration inhibition test.

We have no idea what precipitates the immune disturbance in polymyositis but it is commonly speculated, as mentioned above, that there may be a virus-induced alteration in a muscle surface antigen that causes muscle cells to be attacked by the subject's own lymphocytes. Our findings suggest that this attack is characterised by a reaction between sensitised lymphocytes and antigens on the muscle cell surface, by the rupture of the muscle cell membrane, and the subsequent reaction of sensitised lymphocytes with specific 'contractile protein' within the muscle cell. It remains to be seen whether any comparable diseases affect other 'contractile' cells of the body.

\section{References}

Abbott, J., and Holtzer, H. (1968). The loss of phenotypic traits by differentiated cells. The effect of 5bromodeoxyuridine on cloned chondrocytes. Proceedings of the National Academy of Sciences of the United States of America, 59, 1144-1151.

Abbott, J., Schiltz, J., Dienstman, S., and Holtzer, H. (1974). The phenotypic complexity of myogenic clones. Proceedings of the National Academy of Sciences of the United States of America, 71, 15061510.

Abercrombie, M. (1978). The fibroblast - a prototype. Journal of Clinical Pathology, 31, Supplement (Royal College of Pathologists) 12, 1-6.

Adrian, R. H., and Bryant, S. H. (1974). On the repetitive discharge in myotonic muscle fibres. Journal of Physiology, 240, 505-515.

Afzelius, B. A. (1976). The role of cilia in man. In Contractile Systems in Non-muscle Tissues, edited by S. V. Perry, A. Margreth, and R. S. Adelstein, pp. 275-282. North Holland Publishing Co., Amsterdam and Oxford.

Axelsson, J., and Thesleff, S. (1959). A study of supersensitivity in denervated mammalian skeletal muscle. Journal of Physiology, 147, 178-193.

Bayliss, L. M., and Sloper, J. C. (1973). The role of the circulating cell as a source of myoblasts in the repair of injured skeletal muscle: Evidence derived from the preirradiation of injured tissue and the use of tritiated thymidine. In Basic Research in Myology, edited by B. A. Kakulas, pp. 346-349. International Congress Series No. 294. Excerpta Medica, Amsterdam.

Blume, R. S., and Wolff, S. M. (1972). The ChediakHigashi syndrome: studies in four patients and a review of the literature. Medicine, 51, 247-280.

Booyse, F., Kisieleski, D., Seeler, R., and Rafelson, M., Jr. (1972). Possible thrombosthenin defect in Glanzmann's thrombasthenia. Blood, 39/3, 377-381.

Borgers, M., and De Brabander, M. (editors) (1975). Microtubules and Microtubule Inhibitors, $553 \mathrm{pp}$. NorthHolland Publishing Co., Amsterdam and Oxford.

Boxer, L. A., Hedley-Whyte, E. T., and Stossel, T. P. (1974). Neutrophil actin dysfunction and abnormal neutrophil behavior. New England Journal of Medicine, 291, 1093-1099.

Bray, D. (1977). Actin and myosin in neurones: a first review. Biochimie, 59, 1-6.

Bryant, S. H., and Morales-Aguilera, A. (1971). Chloride conductance and myotonic muscle fibres and the action of monocarboxylic aromatic acids. Journal of Physio$\log y, 219,367-383$. 
Buller, A. T., Mommaerts, W. F. H. M., and Seraydarian, K. (1969). Enzymatic properties of myosin in fast and slow twitch muscles of the cat following cross innervation. Journal of Physiology, 205, 581-597.

Burnstock, G. (1972). Purinergic nerves. Pharmacological Reviews, 24, 509-581.

Butterfield, D. A., Chesnut, D., Roses, A. D., and Appel, S. H. (1974). Electron spin resonance studies of erythrocytes from patients with myotonic muscular dystrophy. Proceedings of the National Academy of Sciences of the United States of America, 71, 909-913.

Chamley, J. H., Gröschel-Stewart, U., Campbell, G. R., and Burnstock, G. (1977). Distinction between smooth muscle, fibroblasts and endothelial cells in culture by the use of fluoresceinated antibodies against smooth muscle actin. Cell and Tissue Research, 177, 445-457.

Cosmos, E. (1974). Muscle transplants: role in the etiology of hereditary muscular dystrophy. In $E x$ ploratory Concepts in Muscular Dystrophy. II. Control Mechanisms in Development and Function of Muscle and their Relations to Muscular Dystrophy and Related Neuromuscular Diseases (International Congress Series, 333), edited by A. T. Milhorat, pp. 368-373. Excerpta Medica, Amsterdam, and American Elsevier Publishing Co., New York.

Crane, W. A. J., and Ingle, D. J. (1965). Cell proliferation in adrenal-regeneration hypertension. Archives of Pathology, 79, 169-176.

Crawford, N. (1978). Personal communication.

Currie, S. (1971). Experimental myositis: the in-vivo and in-vitro activity of lymph-node cells. Journal of Pathology, 105, 169-185.

Curry, O. B., Basten, J. F., Francis, M. J. O., and Smith, R. (1974). Calcium uptake by sarcoplasmic reticulum of muscle from vitamin D-deficient rabbits. Nature (London), 249, 83-84.

Dawkins, R. L. (1965). Experimental myositis associated with hypersensitivity to muscle. Journal of Pathology and Bacteriology, 90, 619-625.

Dean, M. F. (1978). Replacement therapy in mucopolysaccharidoses. Journal of Clinical Pathology, 31, Supplement (Royal College of Pathologists) 12, 120-127.

Dean, M. F., Muir, H., Benson, P. F., Button, L. R., Boyslton, A., and Mowbray, J. (1976). Enzyme replacement therapy by fibroblast transplantation in a case of Hunter's syndrome. Nature (London), 261, 323324.

Diamond, J., and Miledi, R. (1962). A study of fetal and newborn rat muscle fibres. Journal of Physiology, 162, 393-408.

DiMauro, S., and DiMauro, P. M. M. (1973). Muscle carnitine palmityl transferase deficiency and myoglobinuria. Science, 182, 929-931.

Dubowitz, V., and Brooke, M. H. (19-3). Muscle Biopsy: A Modern Approach Major Problems in Neurology, Vol. 2). Saunders, London, Philadelphia, and Toronto.

Eliasson, R., Mossberg, B., Camner, P., and Afzelius, B. A. (1977). The immotile-cilia syndrome: a congenital ciliary abnormality as an etiologic factor in chronic airway infections and male sterility. New England Journal of Medicine, 297, No. 1, 1-6.

Engel, A. G., and Angelini, C. (1973). Carnitine defi- ciency of human skeletal muscle with associated lipid storage myopathy: a new syndrome. Science, 179, 899902.

Engel, A. G., Lambert, E. H., and Gomez, M. R. (1977a). A new myasthenic syndrome with end plate acetylcholin-esterase deficiency, small nerve terminals, and reduced acetyl choline release. Annals of Neurology, 1, 315-330.

Engel, A. G., Lambert, E. H., and Howard, F. M. (1977b). Immune complexes (IgG and $\mathrm{C}_{3}$ ) at the motor endplate in myasthenia gravis: ultrastructural and light microscopic localization and electrophysiologic correlations. Mayo Clinic Proceedings, 52, 267-280.

Engel, A. G., and Santa, T. (1971). Histometric analysis of the ultrastructure of the neuromuscular junction in myasthenia gravis and in the myasthenic syndrome. Annals of the New York Academy of Sciences, 183, 4663.

Engel, A. G., Tsujihata, M., Lambert, E. H., Lindstrom, J. M., and Lennon, V. A. (1976). Experimental autoimmune myasthenia gravis: a sequential and quantitative study of the neuromuscular junction ultrastructure and electrophysiologic correlations. Journal of Neuropathology and Experimental Neurology, 35, 569-587.

Fambrough, D. M., Drachman, D. B., and Satyamurti, S. (1973). Neuromuscular junction in myasthenia gravis: decreased acetylcholine receptors. Science, $\mathbf{1 8 2}$, 293-295.

Farrow, L. J., Holborow, E. J., and Brighton, W. D. (1971). Reaction of human smooth muscle antibody with liver cells. Nature [New Biology], 232, 186-187.

Fischbach, G. D., and Cohen, S. A. (1973). The distribution of acetylcholine sensitivity over uninnervated and innervated muscle fibers grown in cell culture. Developmental Biology, 31, 147-162.

Fischman, D. A. (1972). Development of striated muscle. In The Structure and Functions of Muscle, edited by G. H. Bourne, Vol. 1, 2nd edition, pp. 75-148. Academic Press, London and New York.

Fox, B. (1967). Lipofuscinosis of the gastrointestinal tract in man. Journal of Clinical Pathology, 20, 806-813.

Gabbiani, G., Majno, G., and Ryan, G. B. (1973). The fibroblast as a contractile cell: the myo-fibroblast. In Biology of Fibroblasts, edited by F. Kulonen and J. Pikkarainen, pp. 139-154. Academic Press, London and New York.

Gardner-Medwin, D. (1977). Children with genetic muscular disorders. British Journal of Hospital Medicine, 17, 314-340.

Gibbons, I. R., and Rowe, A. J. (1965). Dynein a protein with adenosine triphosphatase activity from cilia. Science, 149, 424-426.

Godman, G. C. (1958). Cell transformation and differentiation in regenerating striated muscle. In Frontiers in Cytology, edited by S. L. Palay, pp. 381-416. Yale University Press, New Haven.

Goldspink, G., Ed. (1974). Development of muscle. In Differentiation and Growth of Cells in Vertebrate Tissues, pp. 69-99. Chapman and Hall, London.

Gutmann, E., and Zak, R. (1961). Nervous regulation of nucleic acid level in cross-striated muscle: changes in denervated muscle. Physiologia Bohemoslovenica, 10, 
493-500.

Hoffman, H. (1951). Fate of interrupted nerve fibres regenerating into partially denervated muscles. Australian Journal of Experimental Biology and Medical Science, 29, 210-219.

Holtzer, H., Marshall, J. M., and Finck, H. (1957). An analysis of myogenesis by the use of fluorescent antimyosin. Journal of Biophysical and Biochemical Cytology, 3, 705-724.

Huxley, A. F. (1957). Muscle structure and theories of contraction. Progress in Biophysics and Biophysical Chemistry, 7, 255-318.

Huxley, H. E. (1963). Electron miscroscopic studies on the structure of natural and synthetic filaments from striated muscle. Journal of Molecular Biology, 7, 281308.

Huxley, H. E. (1972). Molecular basis of contraction in cross striated muscle. In The Structure and Function of Muscle, edited by G. H. Bourne, 2nd edition, Vol. 1, Part 1, pp. 301-387. Academic Press, New York.

Ishikawa, H., Bischoff, R., and Holtzer, H. (1969). Formation of arrowhead complexes with heavy meromyosin in a variety of cell types. Journal of Cell Biology, 43, 312-328.

Kakulas, B. A. (1966). Destruction of differentiated muscle cultures by sensitized lymphoid cells. Journal of Pathology and Bacteriology, 91, 495-503.

Konigsberg, I. R. (1963). Clonal analysis of myogenesis. Science, 140, 1273-1284.

Kuhn, E. (1973). Myotonia the clinical evidence. In New Developments in Electromyography and Clinical Neurophysiology, edited by J. E. Desmedt, pp. 413-419. Karger, Basel.

Lash, J. W., Holtzer, H., and Swift, H. (1957). Regeneration of mature skeletal muscle. Anatomical Record, 128, 679-693.

Lazarides, E. (1976a). Two general classes of cytoplasmic actin filaments in tissue culture cells: the role of tropomyosin. Journal of Supramolecular Structure, 5, 531 (383)-563 (415).

Lazarides, E. (1976b). Actin, a-actinin and tropomyosin interaction in the structural organisation of actin filaments in non-muscle cells. Journal of Cell Biology, 68, 202-219.

Lemanski, L. F. (1974). Studies of developing myocardial cells in cardiac lethal mutant mexican axolotls ( $A m b y$ stoma mexicanum). In Exploratory Concepts in Muscular Dystrophy II. Control Mechanisms in Development and Function of Muscle and their Relationship to Muscular Dystrophy and Related Neuromuscular Diseases (International Congress Series, 333), edited by A. T. Milhorat, pp. 292-307. Excerpta Medica, Amsterdam, and American Elsevier Publishing Co, New York.

Lennon, V. A., Lindstrom, J. M., and Seybold, M. E. (1976). Experimental autoimmune myasthenia gravis: cellular and humoral immune responses. Annals of the New York Academy of Medical Sciences, 274, 283-299.

Levene, C. I. (1978). Diseases of the collagen molecule Journal of Clinical Pathology 31, Supplement (Royal College of Pathologists) 12, 82-94.

Lindstrom, J. M., Engel, A. G., Seybold, M. E., Lennon,
V. A., and Lambert, E. H. (1976a). Pathological mechanisms in experimental autoimmune myasthenia gravis. II. Passive transfer of experimental autoimmune myasthenia gravis in rats with anti-acetylcholine receptor antibodies. Journal of Experimental Medicine, 144, 739-753.

Lindstrom, J. M., Lennon, V., Seybold, M., and Wittingham, S. (1976b). Experimental autoimmune myasthenia gravis and myasthenia gravis: biochemical and immunochemical aspects. Annals of the New York Academy of Medical Sciences, 274, 254-274.

Lipicky, R. J., and Bryant, S. H. (1973). A biophysical study of the human myotonias. In New Developments in Electromyography and Clinical Neurophysiology, edited by J. E. Desmedt, pp. 451-463. Karger, Basel.

Lockhart, R. D., and Brandt, W. (1938). The length of striated muscle fibres. Proceedings of the Anatomical Society of Great Britain and Ireland. Journal of Anatomy, 72, 470.

Loor, F. (1976). Cell surface design. Nature (London), 264, 272-273.

McArdle, B. (1951). Myopathy due to a defect in muscle glycogen breakdown. Clinical Science, 10, 13-33.

McComas, A. J. (1977). Neuromuscular Function and Disorders. Butterworth, London.

MacLeod, A. R., Waterston, R. H., Fishpool, R. M., and Brenner, S. (1977). Identificaton of the structural gene for a myosin heavy-chain in Caenorhabditis elegans. Journal of Molecular Biology, 114, 133-140.

McMinn, R. M. H. (1969). Tissue Repair. Academic Press, London and New York.

Malawista, S. E. (1975). Effects of colchicine and vinblastine on the mobilization of lysosomes in phagocytizing human leukocytes. In Microtubules and Microtubule Inhibitors, edited by $\mathbf{M}$. Borgers and $M$. de Brabander, pp. 199-206. North-Holland Publishing Co, Amsterdam.

Manghani, D., Partridge, T. A., and Sloper, J. C. (1974). The role of the myofibrillar fraction of skeletal muscle in the production of experimental polymyositis. Journal of Neurological Sciences, 23, 489-503.

Matheson, D. W., and Howland, J. L. (1974). Erythrocyte deformation in human muscular dystrophy. Science, 184, 165-166.

Mauro, A. (1961). Satellite cell of skeletal muscle fibres. Journal of Biophysical and Biochemical Cytology, 9, 493-495.

Mintz, B., and Baker, W. W. (1967). Normal mammalian muscle differentiation and gene control of isocitrate dehydrogenase synthesis. Proceedings of the National Academy of Sciences of the United States of America, 58, 592-598.

Mooseker, M. S., and Tilney, L. G. (1975). Organization of an actin filament-membrane complex. Filament polarity and membrane attachment of the microvilli of intestinal epithelial cells. Journal of Cell Biology, 67, 725-743.

Morgan, G., Peter, J. B., and Newbould, B. B. (1971). Experimental allergic myositis in rats. Arthritis and Rheumatism, 14, 599-609.

Nelson, T. E. (1973). Porcine stress syndromes. In International Symposium on Malignant Hyperthermia, 
edited by R. A. Gordon, B. A. Britt, and W. Kalow, pp. 191-197. Thomas, Springfield, Ill.

Ochs, S. (1971). Characteristics and a model for fast axoplasmic transport in nerve. Journal of Neurobiology, 2, 331-345.

Oliver, J. M. (1975). Defects in cyclic GMP generation and microtubule assembly in Chediak-Higashi and malignant cells. In Microtubules and Microtubule Inhibitors, edited by M. Borgers and M. De Brabander, pp. 341-354. North-Holland Publishing Co, Amsterdam.

Partridge, T. A., and Sloper, J. C. (1977). A host contribution to the regeneration of muscle grafts. Journal of Neurological Sciences, 33, 425-435.

Partridge, T. A., and Smith, P. D. (1976). A quantitative test to detect lymphocytes sensitized against the surface of muscle cells. Clinical and Experimental Immunology, 25, 139-143.

Peachey, L. D. (1966). Fine structure of two fibre types in cut extraoccular muscles. Journal of Cell Biology, 31, $84 \mathrm{~A}$.

Pinching, A. J., Peters, D. K., and Davis, J. Newsom (1976). Remission of myasthenia gravis following plasma exchange. Lancet, 2, 1373-1376.

Rees, D. A., Lloyd, C. W., and Thom, D. (1977). Control of grip and stick in cell adhesion through lateral relationships of membrane glycoproteins. Nature (London), 267, 124-128.

Romanul, F. C. A., and Van der Meulen, T. P. (1966). Reversal of enzyme profiles of muscle fibres in fast and slow muscles by cross-innervation. Nature (London), 212, 1369-1370.

Roses, A. D., and Appel, S. H. (1973). Protein kinase activity in erythrocyte ghosts of patients with myotonic dystrophy. Proceedings of the National Academy of Sciences of the United States of America, 70, 1855-1859.

Ryman, B. E. (1974). The glycogen storage diseases. Journal of Clinical Pathology, 27, Suppl., 8, 106-121.

Salmons, S., and Sreter, F. A. (1976). Significance of impulse activity in the transformation of skeletal muscle type. Nature (London), 263, 30-34.

Sanger, J. W., Holtzer, S., and Holtzer, H. (1971). Effects of cytochalasin B on muscle cells in tissue culture. Nature New Biology, 229, 121-123.

Schollmeyer, J. V., Goll, D. E., Stromer, M. H., Dayton, W., Singh, I., and Robson, R. (1974a). Studies on the composition of the $\mathrm{Z}$ disk. Journal of Cell Biology, 63, 303a.

Schollmeyer, J. V., Goll, D. E., Tilney, L. G., Mooseker, M., Robson, R., and Stromer, M. (1974b). Localization of $a$-actinin in non-muscle material. Journal of Cell Biology, 63, 304a.

Schott, G. D., and Wills, M. R. (1976). Muscle weakness in osteomalacia. Lancet, 1, 626-629.

Shortland, J. R., Fernandez, D., and Crane, W. A. J. (1970). Electron miscroscopy of renal arteries after partial aortic constriction. Journal of Pathology, 101, viii (abstr.).
Simpson, J. A. (1960). Myasthenia gravis: a new hypothesis. Scottish Medical Journal, 5, 419-436.

Sloper, J. C., and Grainger, F. (1975). Quantitation of microtubules in secretory neurons. In Microtubules and Microtubule Inhibitors, edited by $\mathbf{M}$. Borgers and M. De Brabander, pp. 281-287. North-Holland Publishing Co, Amsterdam.

Sloper, J. C., and Pegrum, G. D. (1967). Regeneration of crushed mammalian skeletal muscle and effects of steroids. Journal of Pathoiogy and Bacteriology 93, 47-63.

Small, J. V., and Squire, J. M. (1972). Structural basis of contraction in vertebrate smooth muscle. Journal of Molecular Biology, 67, 117-149.

Smith, P. D., and Partridge, T. A. (1976). Macrophage migration inhibition studies of lymphocytes taken from guinea-pigs suffering from experimental polymyositis. Clinical and Experimental Immunology, 25, 133-138.

Studitsky, A. N. (1974). The neural factor in the development of transplanted muscles. In Exploratory Concepts in Muscular Dystrophy II. Control Mechansisms in Development and Function of Muscle and their Relationship to Muscular Dystrophy and Related Neuromuscular Diseases (International Congress Series, 333) edited, by A. T. Milhorat, pp. 351-366. Excerpta Medica, Amsterdam, and American Elsevier Publishing Co, New York.

Swash, M., and Fox, K. P. (1976). The pathology of the muscle spindle in Duchenne muscular dystrophy. Journal of Neurological Sciences, 29, 17-32.

Walker, B. E. (1963). The origin of myoblasts and the problem of dedifferentiation. Experimental Cell Research, 30, 80-92.

Walton, J. N., and Adams, R. P. (1958). Polymyositis. Livingston, Edinburgh and London.

Walton, J. N., and Natrass, F. J. (1954). On the classification, natural history and treatment of the myopathies. Brain, 77, 169-231.

Weber, K. (1975). Specific visualization of tubulin containing structures by immunofluorescence microscopy: cytoplasmic microtubules, rinblastine induced paracrystals and mitotic figures. In Microtubules and Microtubule Inhibitors, edited by $\mathbf{M}$. Borgers and $\mathbf{M}$. De Brabander, pp. 313-325. North-Holland Publishing Co, Amsterdam.

Weber, K., and Groeschel-Stewart, U. (1974). Antibody to myosin: the specific visualization of myosincontaining filaments in nonmuscle cells. Proceedings of the National Academy of Sciences of the United States of America, 71, 4561-4564.

Wessells, N. K., Spooner, B. S., Ash, J. F., Bradley, M. O., Luduena, M. A., Taylor, E. L., Wrenn, J. T., and Yamada, K. M. (1971). Microfilaments in cellular and developmental processes. Science, 171, 135-143.

Willingham, M. C., Ostlund, R. E., and Pastan, I. (1974). Myosin is a component of the cell surface of cultured cells. Proceedings of the National Academy of Sciences of the United States of America, 71, 4144-4148. 